\title{
Functional and Pasting Properties of Maize 'Ogi' Supplemented with Fermented Moringa Seeds
}

\author{
Jude-Ojei BS ${ }^{1}$, Lola A $^{2 *}$, Ajayi $1 O^{3}$ and Ilemobayo Seun ${ }^{2}$ \\ ${ }^{1}$ Department of Nutrition and Dietetics, Rufus Giwa Polytechnic, Owo Ondo State, Nigeria \\ ${ }^{2}$ Department of Food Science and Technology, Rufus Giwa Polytechnic, Owo Ondo State, Nigeria \\ ${ }^{3}$ Department of Science Laboratory Technology, Rufus Giwa Polytechnic, Owo Ondo State, Nigeria
}

\begin{abstract}
The process of Ogi production results in remarkable nutrient loss, Moringa seed flour, rich in micronutrients and vitamins, could increase the micronutrient and macronutrient contents of ogi. This study aimed at evaluating the functional and pasting properties of 'ogi' supplemented with fermented Moringa seeds. Moringa seeds was de-feathered and fermented for $48 \mathrm{~h}$, dried and milled into flour. Maize 'ogi' was produced following traditional methods. Maize-Moringa Ogi was formulated by mixing the samples in ratio $90: 10,80: 20$ and $70: 30$ while $100 \%$ maize and 100\% Moringa flour serves as control. The functional properties, shows that the swelling capacity ranged between $(0.94 \mathrm{ml}$ to $0.74 \mathrm{ml})$, water absorption (18 $\mathrm{ml}$ to $13 \mathrm{ml})$ and bulk density $(0.66$ $\mathrm{g} / \mathrm{ml}$ to $0.36 \mathrm{~g} / \mathrm{ml}$ ), and the least gelation for $10 \%$ to $30 \%$ Moringa seed inclusion results showed no gelation at $2 \%, 4 \%, 6 \%$ and $8 \%$, weak gel at $10 \%, 12 \%, 14 \%$ and $16 \%$ and strong gel at $18 \%$ and $22 \%$. In pasting properties, the result of peak viscosity of the samples ranged between (3552.67 RVA to 15.00 RVA), trough (1842.33 RVA to 8.50 RVA), breakdown (1717.33 RVA to 7.00 RVA), final viscosity (3926.67 RVA to 12.00 RVA), set back (2084.67 RVA to $4.00 \mathrm{RVA}$ ) and peak time (5.00 to $4.47 \mathrm{~min}$ ). The addition of Moringa seed flour to maize-'ogi' reduced the functional and pasting properties.
\end{abstract}

Keywords: 'Ogi'; Moringa; Pasting properties; Functional properties

\section{Introduction}

Ogi a fermented gruel from cereal has been recognized as the most popular traditional health-sustaining fermented food in Western Nigeria. It is commonly used as weaning food, food for convalescence, young children and as a standard breakfast cereals in many homes. Ogi usually has smooth texture and is boiled into porridge called pap or cooked and turned into a stiff gel called "agidi" or "eko" prior to consumption [1].

Traditional preparation of 'ogi' involved washing, steeping, milling, sieving, fermentation and drying. During these processes, nutrients including protein and minerals are lost from the grains thereby affecting nutritional quality adversely $[2,3]$. Various studies have been carried out to improve the nutritional value of 'ogi' by fortifying it with either plant protein (melon, okro, cowpea, and soybean) or animal protein sources (egg and milk) [4,5]. The application of Moringa for this purpose is however limited to the leaves [6]. Moringa oleifera, is known by different names such as benzolive, drumstick tree, kelor, marango, mlonge, mulangay, nébéday, saijhan, and sajna across many regions. It is the most widely cultivated species of a monogeneric family, the Moringaceae, which is native to the sub-Himalayan tracts of India, Pakistan, Bangladesh and Afghanistan. All the parts of the tree have been reported to be edible and are consumed in many parts of the world [7]. Moringa oleifera will be one of the alternatives to most imported food supplies in the treatment of malnutrition. The diet of many rural and urban dwellers is deficient in protein and high in carbohydrate. The plant seeds contain hypotensive activity, strong antioxidant activity and chelating property against arsenic toxicity [8-11]. Seed flour from Moringa oleifera is widely used as a natural coagulant for water treatment in developing countries [11]. It has an impressive range of medicinal uses with high nutritional quality

When starch-based foods are heated in an aqueous environment, they undergo a series of changes known as gelatinization and pasting. These are two of the most important properties that has effect on quality and aesthetic concerns in the food industry, since they affect texture and digestibility as well as the end use of starchy foods [12]. The aim of this paper therefore is to determine how the addition of fermented Moringa seed will affect the functional and pasting properties of maize 'ogi'.

\section{Materials and Methods}

\section{Materials}

'Swan 1'maize used in this research was purchased from let's farm Agric input store, Akure, Ondo State, Nigeria. The grains were dry when purchased and the Moringa seeds were harvested from the School experimental farm.

\section{Methods}

Preparation of Moringa flour: Fermentation of the seeds was achieved by soaking in water and allowed to ferment for 2 days at ambient temperature. Fermented samples were dried at $50^{\circ} \mathrm{C} \pm 5^{\circ} \mathrm{C}$ until constant moisture content was obtained. The dried samples were milled using disc milling machine. The milled samples were kept in air tight plastic container until needed.

Preparation of Maize 'ogi' flour: The method described by Akingbala [2] was used for 'ogi' manufacture. Maize grain (1 kg) was soaked in water for $48 \mathrm{~h}$. The grain was milled with attrition mill at medium speed for $7 \mathrm{~min}$. The slurry was passed through muslin cloth and the suspension obtained was left to stand for $48 \mathrm{~h}$ for the 'ogi' to sour, the supernanant was decanted to be able to collect the 'ogi'. 'Ogi'

*Corresponding author: Lola A, Department of Food Science and Technology, Rufus Giwa Polytechnic, Owo Ondo State, Nigeria, Tel: †2348034730783; E-mail lola_ajala2006@yahoo.co.uk

Received April 19, 2017; Accepted May 08, 2017; Published May 15, 2017

Citation: Jude-Ojei BS, Lola A, Ajayi IO, Seun I (2017) Functional and Pasting Properties of Maize 'Ogi' Supplemented with Fermented Moringa Seeds. J Food Process Technol 8: 674. doi: 10.4172/2157-7110.1000674

Copyright: (C) 2017 Jude-Ojei BS, et al. This is an open-access article distributed under the terms of the Creative Commons Attribution License, which permits unrestricted use, distribution, and reproduction in any medium, provided the original author and source are credited. 


\begin{tabular}{|c|c|c|c|}
\hline $\begin{array}{c}\text { Level of } \\
\text { substitution }\end{array}$ & $\begin{array}{c}\text { Swelling capacity } \\
\mathbf{( g / m l )}\end{array}$ & $\begin{array}{c}\text { Water absorption } \\
(\mathbf{m l})\end{array}$ & $\begin{array}{c}\text { Bulk density (g/ } \\
\mathbf{m l})\end{array}$ \\
\hline $100 \%$ maize 'ogi' & $0.94^{\mathrm{a}}$ & $18^{\mathrm{a}}$ & $0.66^{\mathrm{a}}$ \\
\hline $10 \%$ FMOSD & $0.89^{\mathrm{b}}$ & $16^{\mathrm{b}}$ & $0.57^{\mathrm{b}}$ \\
\hline $20 \%$ FMOSD & $0.86^{\mathrm{c}}$ & $15^{\mathrm{b}}$ & $0.57^{\mathrm{b}}$ \\
\hline $30 \%$ FMOSD & $0.84^{\mathrm{c}}$ & $14^{\mathrm{bc}}$ & $0.55^{\mathrm{c}}$ \\
\hline $100 \%$ Moringa & $0.74^{\mathrm{d}}$ & $13^{\mathrm{c}}$ & $0.36^{\mathrm{d}}$ \\
\hline \multicolumn{2}{|l}{} \\
\hline
\end{tabular}

Table 1: Functional properties of maize-'ogi' supplemented with fermented Moringa seed.

was dried at $50^{\circ} \mathrm{C} \pm 5^{\circ} \mathrm{C}$ until constant weight was obtained and was crushed manually.

Preparation of Moringa-'Ogi' flour mixtures: Moringa-'ogi' flour was produced by mixing dry 'ogi' powder with fermented Moringa seed flour. Formulation of Moringa-'ogi' was at different mixing ratio of 0:100, 10:90, 20:80, and 30:70 of Moringa and 'ogi', respectively. Samples were kept in air tight container until when needed.

\section{Determination of Functional Properties}

\section{Water absorption capacity}

The procedure of Sathe et al. [13] was used. To $1.0 \mathrm{~g}$ of each sample was added $10 \mathrm{ml}$ of water, the suspension was then stirred using magnetic stirrer for $5 \mathrm{~min}$. and was transferred into centrifuge tubes and centrifuged at 3,500 $\mathrm{rpm}$ for $30 \mathrm{~min}$. The supernatant that was obtained was measured using a $10 \mathrm{ml}$ measuring cylinder. The density of the water was assumed to be $1 \mathrm{~g} / \mathrm{ml}$. The water absorbed was calculated as the difference between the initial volume of water used and the volume of the supernatant obtained after centrifugation. The result was expressed as a percentage of water absorbed by the samples on percentage $\mathrm{g} / \mathrm{g}$ basis.

\section{Least gelation concentration (LGC)}

The LGC of the flour blends was determined using the modified method of Coffman and Garcia [14]. Sample suspensions of $2 \%, 4 \%$, $6 \%, 8 \%, 12 \%, 14 \%, 16 \%, 18 \%$ and $20 \%(\mathrm{w} / \mathrm{v})$ was prepared in $10 \mathrm{ml}$ distilled water in test tubes. The tubes containing the suspensions was then heated for $1 \mathrm{~h}$ in a gentle boiling water bath. The tubes were cooled rapidly in water at $40^{\circ} \mathrm{C}$ for $2 \mathrm{~h}$. Each tube was inverted one after the other. The LGC was taken as the concentration when the sample from the inverted test tube did not fall or slip.

\section{Swelling capacity and solubility}

The method described by Leach et al. [15] was used with slight modifications Sample (1 g) was weighed and transferred into a clean, dry test tube and weighed $\left(\mathrm{W}_{1}\right)$. The flour was then dispersed in 50 $\mathrm{ml}$ of distilled water using a magnetic stirrer. The resulting slurry was heated at desired temperatures $\left(40^{\circ} \mathrm{C}, 50^{\circ} \mathrm{C}, 60^{\circ} \mathrm{C}\right.$ and $\left.70^{\circ} \mathrm{C}\right)$ for $30 \mathrm{~min}$ in a thermostatically controlled water bath. The mixture was cooled to room temperature and centrifuged at 2,200 rpm for $15 \mathrm{~min}$. Aliquot of the supernatant $(5 \mathrm{ml})$ was dried to a constant weight at $120^{\circ} \mathrm{C}$. The residue obtained after drying represented the amount of starch solubilized in water. Solubility was calculated as per $100 \mathrm{~g}$ of starch on dry weight basis. The residue obtained after centrifugation with the water it retained was transferred to the clean, dried test tube and weighed $\left(\mathrm{W}_{2}\right)$.

$$
\text { Swelling capacity of starch }=\frac{w_{2}-w_{1}}{\text { Weight of flour }} \times 100
$$

\section{Determination of pasting properties}

The pasting profile of the samples was studied using a rapid Visco-Analyzer (RVA) (Newport Scientific Pty. Ltd) with the aid of a thermocline for windows version 1.1 [16]. The RVA was connected to a PC where the pasting properties and curve were recorded. Sample suspension was then prepared by addition of the equivalent weight of $3.0 \mathrm{~g}$ dry starch to distilled water to make a total weight of $28.0 \mathrm{~g}$ suspension in the RVA sample canister

\section{Data Analysis}

Data collected were statistically analyzed with the Statistical Analysis Systems (SAS) package (version 8.2 of SAS institute Inc, 1999) [17]. Statistically significant differences $(p \leq 0.05)$ in all data were determined by general linear model procedure (GLM) while least significant difference (LSD) was used to separate the means. Correlation coefficient between variables was obtained using Pearson correlation coefficient analysis.

\section{Results and Discussion}

The result of the functional properties of maize 'ogi' supplemented with mature Moringa seed is presented in Table 1. The results show that there was gradual decrease in the level of water absorption capacity and bulk density as the addition of Moringa seed flour increases. These compared favorably with the result obtained by substituting 'ogi' with bambara-nut flour by Theodore et al. [18], the decrease in water absorption capacity contents is in line with a conclusion made by Theodore et al. [18], which states that a weaning food should have low water absorption capacity and bulk density in order to have high energy density food which are more suitable as weaning food. According to Omueti et al. [19] lower water absorption capacity is desirable for making thinner gruels with high caloric density per unit volume. Also, according to Onuoha [20] low bulk density is an advantage because high bulk limits the caloric and nutrient intake per feed per child and infants sometimes are unable to consume enough to satisfy their energy and nutrient requirements. Swelling capacity which is the measure of the ability of starch to imbibe water and swell, ranged from 0.74 to 0.94 . The $100 \%$ 'ogi' sample had the highest value (0.94), while the $100 \%$ of Moringa sample had the lowest (0.74). The mixed samples had significant different swelling capacity. The swelling index of granules reflects the extent of associative forces within the granules as reported by Sanni et al. [21]. The swelling capacity of the supplemented sample indicated that the associative forces within their granules were not strongly bonded.

Results of least gelation properties of maize 'ogi' supplemented with mature Moringa seed is presented in Table 2. Maize-'ogi' formed weak gel between $6 \%$ and $10 \%$ concentration while a strong gel was at $12 \%$ concentration and $100 \%$ Moringa formed no gel in all the concentration. Maize-Moringa 'ogi' samples at the $10 \%, 20 \%, 30 \%$ level of Moringa seed substitution formed a weak gel between $10 \%$ and $16 \%$ concentrations. A strong gel was however, formed at $18 \%$ concentration. Yadav [22] observed that the variation in the gelling properties of flours could be attributed to the relative ratio of protein, carbohydrates and lipids that makes up the flours and the interaction between the components. From this result, Food prepared from maize 'ogi' substituted with fermented Moringa seed will contain more food and therefore nutrients than food produced from $100 \%$ maize-'ogi'

The result of the pasting properties of maize 'ogi' supplemented with mature Moringa seed is presented in Table 3. From this result, the peak viscosity of the 'ogi' samples ranged between 15.00 RVA and 


\begin{tabular}{|c|c|c|c|c|c|c|c|c|c|c|}
\hline Samples & $2 \%$ & $4 \%$ & $6 \%$ & $8 \%$ & $10 \%$ & $12 \%$ & $14 \%$ & $16 \%$ & $18 \%$ & $22 \%$ \\
\hline 100\% Maize'ogi' & $x$ & $x$ & $\mathrm{Y}$ & $\mathrm{Y}$ & $Y$ & $\sqrt{ }$ & $\sqrt{ }$ & $\sqrt{ }$ & $\sqrt{ }$ & $\sqrt{ }$ \\
\hline $10 \%$ FMOSD & $x$ & $x$ & $x$ & $x$ & $\mathrm{Y}$ & $Y$ & $\mathrm{Y}$ & $\mathrm{Y}$ & $\sqrt{ }$ & $\sqrt{ }$ \\
\hline $20 \%$ FMOSD & $x$ & $x$ & $x$ & $x$ & $\mathrm{Y}$ & $Y$ & $\mathrm{Y}$ & $Y$ & $\sqrt{ }$ & $\sqrt{ }$ \\
\hline $30 \%$ FMOSD & $x$ & $x$ & $x$ & $x$ & $\mathrm{Y}$ & $Y$ & $\mathrm{Y}$ & $Y$ & $\sqrt{ }$ & $\sqrt{ }$ \\
\hline $100 \%$ Moringa & $x$ & $\mathrm{x}$ & $\mathrm{x}$ & $x$ & $x$ & $\mathrm{x}$ & $x$ & $\mathrm{x}$ & $x$ & $x$ \\
\hline
\end{tabular}

Table 2: Least gelation properties of maize 'ogi' supplemented with fermented Moringa seed.

\begin{tabular}{|c|c|c|c|c|c|c|c|}
\hline $\begin{array}{l}\text { Level of Moringa } \\
\text { Substitution }\end{array}$ & $\begin{array}{c}\text { Peak Viscosity } \\
\text { (RVA) }\end{array}$ & $\begin{array}{l}\text { Trough } \\
\text { (RVA) }\end{array}$ & $\begin{array}{l}\text { Break Down } \\
\text { (RVA) }\end{array}$ & $\begin{array}{l}\text { Final Viscosity } \\
\text { (RVA) }\end{array}$ & $\begin{array}{l}\text { Set Back } \\
\text { (RVA) }\end{array}$ & $\begin{array}{l}\text { Peak Time } \\
\text { (min) }\end{array}$ & $\begin{array}{l}\text { Pasting Temp } \\
\text { (RVA) }\end{array}$ \\
\hline $0 \%$ & 3552.67 & 1842.33 & 1717.33 & 3926.67 & 2084.67 & 5.00 & 75.02 \\
\hline $10 \%$ & 1386.00 & 802.00 & 584.00 & 1442.00 & 9640.00 & 5.13 & 77.55 \\
\hline $20 \%$ & 1185.00 & 686.00 & 499.00 & 1228.00 & 542.00 & 5.13 & 77.45 \\
\hline $30 \%$ & 944.00 & 567.00 & 377.00 & 963.00 & 396.00 & 5.07 & 79.05 \\
\hline $100 \%$ & 15.00 & 8.50 & 7.00 & 12.00 & 4.00 & 4.47 & ------ \\
\hline
\end{tabular}

Table 3: Pasting properties of maize-ogi supplemented with fermented moringa seed

3552.67 RVA. The 100\% 'ogi' sample had the highest peak viscosity while $100 \%$ Moringa seed flour has the lowest. The peak viscosity in the 'ogi' samples reduced with increase in the level of substitution with fermented Moringa seed. This is an indication that fermented Moringa seed flour has no ability to gel. This trend was also observed in some of the earlier studies $[4,23,24]$ on the substitution of 'ogi' with okra seed flour and in the study of Theodore et al. [18] on the substitution of 'ogi' with Bambara-nut. Two factors interact to determine the peak viscosity of cooked starch paste: the extent of granule swelling (swelling capacity) and solubility. Higher swelling index is indicative of higher peak viscosity while higher solubility as a result of starch degradation results in reduced paste viscosity.

The trough of the 'ogi' samples ranged between 8.50 RVA and 1842.33 RVA. $100 \%$ 'ogi' sample had the highest value of 1842.33 RVA while $100 \%$ Moringa had the lowest value of 8.50 RVA. The trough which shows the holding capacity of the starch granules showed that $100 \%$ maize 'ogi' had superior holding capacity due to the crystalline and strength of the starch molecules in it. This implied that $100 \%$ maize 'ogi' has ability to withstand breakdown cooling. The breakdown viscosity value is an index of the stability of starch [25]. The value in this study ranged between 7.00 RVA and 1717.33 RVA. 100\% maize 'ogi' had the highest value of 1717.33 RVA while $100 \%$ Moringa 'ogi' had the lowest value of 7.00RVA. The breakdown viscosity values for all the samples were lower than the peak viscosity values and this is altered by nature of the material, degree of mixing, the temperature used and shear applied to the mixture [16]. The final viscosity which is the change in the viscosity after holding cooked starch at $50^{\circ} \mathrm{C}$, indicates the ability of the material to form a viscous gel or paste after cooking and cooling as well as the resistance of the paste to shear force during stirring [26].

The final viscosity of the 'ogi' samples ranged between 12.00 RVA and 3926.67 RVA. $100 \%$ maize 'ogi' had the highest of 3926.67 RVA while $100 \%$ Moringa had the lowest value of 12.00 RVA. The final viscosity was also affected by the mixture of Moringa into the maize. Setback viscosity is an indication of the stability of cooked paste against retrogradation and can be used to predict the storage life of a product prepared from the flour. The setback value ranged between 2084.67 RVA and 396.00 RVA. From the result $100 \%$ maize-'ogi' had the highest value of 2084.67 while $100 \%$ Moringa had the lowest value of 4.00. The setback revealed the gelling ability or retrogradation tendency of the amylase present in the starch. The low setback values of the sample indicate low rate of retrogradation. This implication of this is that maize-Moringa 'ogi' may not retrogade fast [27].
The peak time of the 'ogi' samples, which is a measure of the cooking time, ranged between 4.47 minutes in 100\% Moringa and 5.13 minutes in $10 \%$ and $20 \%$ samples were significantly different from one another. The pasting temperature ranged between $75.02^{\circ} \mathrm{C}$ and $79.05^{\circ} \mathrm{C} .100 \%$ fermented Moringa seed flour has no ability to gel hence showed no pasting temperature. The gelatinization time during processing could not be confirmed in $100 \%$ Moringa 'ogi' sample. Pasting temperature is an index that characterized the initial change due to swelling of starch [27]. It can be deduced from this study that the mixture (ratio) reduced the inherent characteristic of $100 \%$ maize 'ogi' as seen as the loss in its pasting properties.

\section{Conclusion}

The addition of Moringa seed flour sample to 'ogi' increased the protein content, fibre, ash and fat content but reduced the moisture content. And the reduction of functional and pasting properties controlled the starchy swollen granules in the food sample. Therefore, it would be necessary to encourage the use Moringa seed flour as protein source to supplement the local/traditional cereals such as maize, millet and sorghum based which will reduce the incidence of malnutrition.

\section{Acknowledgement}

This Research was sponsored by Tertiary Education Trust Fund and we appreciate the sponsorship. I also acknowledge the effort of Dr. (Mrs.) Lola Ajala for guidance and effort for the completion of this research work.

\section{References}

1. Faber M, Jogessar VB, Benade AJ (2001) Nutritional status and dietary intakes of children aged 2-5 years and their care-givers in a rural South African community. Int J Food Sci Nutr 52: 401-411.

2. Akingbala JO, Rooney LW, Faubion JM (1981) A laboratory procedure for the preparation of ogi, a Nigerian fermented food. J Food Sci 46: 1523-1526.

3. Adeyemi IA, Beckley O (1986) Effect of period of maize fermentation and souring on chemical properties and amylograph pasting viscosity of ogi. $\mathrm{J}$ Cereal Sci 4: 353-360.

4. Aminigo ER, Akingbala JO (2004) Nutritive composition and sensory properties of ogi fortified with okra seed meal. J Appl Sci Environ Manag 8: 23-28.

5. Oyarekua MA (2010) Sensory evaluation, nutritional quality and anti-nutritiona factors of traditionally co-fermented cereals/cowpea mixtures as infant complementary food. Agri Biol J North America 1: 950-956.

6. Olorode OO, Idowu MA, Ilori OA (2013) Effect of benoil (Moringa oleifera) leaf powder on the quality characteristics of 'Ogi'. America J Food Nutri Sci Huß. 
Citation: Jude-Ojei BS, Lola A, Ajayi IO, Seun I (2017) Functional and Pasting Properties of Maize 'Ogi' Supplemented with Fermented Moringa Seeds. J Food Process Technol 8: 674. doi: 10.4172/2157-7110.1000674

Page 4 of 4

7. Fahey JW (2015) Moringa oleifera: A review of the medical evidence for its nutritional, therapeutic, and prophylactic properties. Tree Life J 1: 5 .

8. Arabshahi DS, Devi DV, Urooj A (2007) Evaluation of antioxidant activity of some plant extracts and their heat, $\mathrm{pH}$ and storage stability. Food Chem 100 $1100-1105$

9. Ghasi S, Nwobodo E, Ofili JO (2000) Hypocholesterolemic effects of crude extract of leaf of Moringa oleifera lam in high-fat diet fed wistar rats. J Ethnopharmacol 69: 21-25.

10. Mehta LK, Balaraman R, Amin AH, Bafna PA, Gulati OD (2003) Effect of fruits of Moringa oleifera on the lipid profile of normal and hyper cholesterolaemic rabbits. J Ethnopharmacol 86: 191-195.

11. Santos AFS, Luciana A, Adriana CCA, Teixeira JA, Paiva PMG, et al. (2009) Isolation of a seed coagulant Moringa oleifera lectin. Process Biochem 44 504-508.

12. Adebowale YA, Adeyemi IA, Oshodi AA (2005) Functional and physicochemical properties of flours of six Mucuna species. Afr J Biotechn 4: 1461-1468.

13. Sathe SK, Deshpande SS, Salunkhe DK (1982) Functional properties of winged bean (Psophocarpus tetragonolobus) proteins. J Food Sci 47: 544-549.

14. Coffman CW, Gracia VV (1977) Functional properties of amino acid content of a protein isolate from mung bean flour. J Food Technol 12: 473-484

15. Leach HW, McCowen LD, Scoch TJ (1959) Structure of starch granules swelling and solubility pattern of various starches. Cereal Chem 36: 534-544.

16. Newport Scientific (1998) Applications manual for the rapid visco analyzer using thermocline for windows. Newport Scientific Pty Ltd., Apollo Street, Warriewood NSW, Australia.

17. SAS (2002) Statistical analysis system proprietary software. Release 8.3 SAS Institute Inc., Carry, NC.
18. Theodore IM, Ikenebomeh MJ, Ezeibe S (2009) Evaluation of mineral content and functional properties of fermented maize (Generic and Specific) flour blended with Bambara Groundnut (Vigna subterranean). Afr $\mathrm{J}$ of $\mathrm{Fd}$ Sci 3: 107-112.

19. Omueti O, Otegbayo B, Jaiyeola O, Afolabi O (2009) Functional properties of complementary diets developed from soybean (Glycine max) and Groundnut 8: 563-573.

20. Onuoha OG, Chibuzo E, Badau M (2014) Studies on the potential of malted Digitaria exilis, Cyperus esculentus and Colocasia esculenta flour blends as weaning food formulation. Nigeria Food J 32: 40-47.

21. Sanni L, Maziya DB, Akanya J, Okoro Cl, Alaya V, et al. (2005) Standards for cassava products and guidelines for export. IITA, Ibadan, Nigeria 93.

22. Yadav RB, Yadav BS, Dhull N (2012) Effect of incorporation of plantain and chickpea flours on the Quality Characteristics of biscuits. J Food Sci Techno 49: 207-13.

23. Akingbala JO, Akinwande BA, Uzo-Peters PI (2005) Effects of color and flavor changes on acceptability of ogi supplemented with okra seed meals. PIt Fd Hum Nutri 58: 1-9.

24. Otunola ET, Sunny-Roberts EO, Solademi AO (2007) Influence of the addition of okra seed flour on the properties of 'ogi', a Nigerian fermented maize food. University of Göttingen, Germany.

25. Fernande De Tonella, ML Berry JW (1989) Rheological properties of flour and sensory characteristics of bread made from germinated chick peas. Int J Food Sci Technol 24: 103-110.

26. Adeyemi IA, Idowu MA (1990) The evaluation of pre-gelatinized maize flour in the development of maissa, a baked product. Nigeria Food J 8: 63-73.

27. Eniola L, Delarosa LC (1981) Physiochemical characteristics of yam starches. J Food Biochemistry 5: 115-130. 